\title{
ANALISIS KONSTRUKSI RANGKA ALAT PENGUJIAN POMPA MENGGUNAKAN PROGRAM CATIA V5
}

\author{
Basori dan Rudianto \\ JurusanTeknik Mesin, FakultasTeknik dan Sains, UniversitasNasional \\ e-mail : ory_banjarn@yahoo.com
}

\begin{abstract}
ABSTRAK
Metode analisis yang diterapkan pada rangka alat pengujian pompa adalah analisis manggunakan progaram Catia V5. Program Catia V5dirancangdandibuatuntuk mempermudah pekerjaan-pekerjaan teknik diantaranya konstruksi, desain, perpipaan, kelistrikan dan lain-lain. Catia memeiliki fitur yang cukup lengkap sehingga mampu melakukan CAD (Computer Aided Desain), CAM (Computer Aided Manufacture) dan CAE (Computer Aided Engineering). CATIA V5 juga mampu melakukan analisis secara 3D pada perancangan konstruksi rangka peralatan pengujian pompa. Diharapkan dari penelitian terhadap rangka yang digunakan pada alat pengujian pompa ini didapatkan suatu hasil analisis yang memadai, dan dari data-data diperoleh itu pula dapat digunakan sebagai acuan untuk upaya-upaya perbaikan serta menyatakan tingkat kelayakan rangka alat pengujian pompa.Dalam mendesain atau merancang sebuah rangka diperlukan urutan kerjayang sistematis dan terencana guna mendapatkan hasil kerja yang optimal.Dimulai dari identifikasi masalah, perumusan masalah, modeling, pemilihan bahan kemudian diinput pada Catia V5 danselanjutnyadilakukan perhitungan dengan Catai V5, jika rangka memenuhi spesifikasi maka akan dilanjutkan ke analisis serta kesimpulan, jika tidak maka akan kembali lagi ke modeling.Distribusi tegangan dan regangan pada rangka alat pengujian pompa ditunjukan dengan variasi warna pada hasil analisis dengan program Catia V5. Tegangan maksimum yang diterima rangka adalah sebesar 7.63027 × $106 \mathrm{~N} / \mathrm{m}^{2}$ terletak pada kaki rangka dibawah piston pump. Spesifikasi rangka alat pengujian pompa adalah baja siku SC 40 dengan panjang $1000 \mathrm{~mm}$, lebar $540 \mathrm{~mm}$ dan tinggi $820 \mathrm{~mm}$. Material konstruksi alat pengujian pompa adalah baja SC 40 dengan batas tegangan bahan yang diijinkan yaitu sebesar $2.5 \times 108 \mathrm{~N} / \mathrm{m}^{2}$. Defleksi maksimum yang terjadi pada rangka alat pengujian pompa sebesar $0.0699382 \mathrm{~mm}$, terletak pada bagian atas rangka yaitu pada dudukan hydromotor.
\end{abstract}

Kata Kunci :Rangka, Pompa, Catia V5, Pengujian

\section{PENDAHULUAN}

\subsection{Latar Belakang}

Pompa adalah salah satu mesin konversi energi yang memiliki peranan penting dalam kehidupan rumah tangga maupun industri. Pompa memiliki fungsi sebagai sebuah instrumen yang digunakan untuk memindahkan fluida dari tempat rendah ke tempat yang lebih tinggi.Dalam aplikasinya pompa dirancang sebagai pengganti tugas manusia untuk memindahkan fluida serta melakukanya denganlebih efektif dan efisien.

Keberadaan peralatan penguji pompapompa akan sangat bermanfaat dalam rangka meningkatkan pemahaman terhadap fenomena aliran yang terjadi pada beberapa jenis pompa yang berbeda.
Salah satu komponen penting pada peralatan enguji pompa-pompa adalah konstruksi rangka. Konstruksi rangka berperan sebagai penopang sekaligus sebagai dudukan bagi komponenkomponen alat penguji. Instrumen penguji pompa-pompa yang baik harus didukung oleh kerangka yang kokoh dan kuat, oleh karena itu perlu dilakukan suatu langkah untuk menganalisiskemampuanrangkatersebutdalam menopang komponen-komponen pengujian pompa.

Metode analisis yang diterapkan pada rangka alat pengujian pompa adalahanalisis manggunakan progaram Catia V5. Catia (Computer Aided Three Dimensional Interactive Application) adalah salah satu program komputer yangdikembangkan oleh perusahaan perangkat lunak (software) bernama IBM.Program Catia V5 diciptakan untuk mempermudah pekerjaan- 
pekerjaan teknikdiantaranya konstruksi, desain, perpipaan, kelistrikan dan lainlain.Catiamemeiliki fitur yang cukup lengkap sehingga mampu melakukan CAD (ComputerAided Desain), CAM (Computer Aided Manufacture) dan CAE (Computer AidedEngineering).

Analisis terhadap rangka alatpengujian pompainidiharapkanmampumenghasilkandatadatayang memadaisebagai acuan untuk upayaupayaperbaikan serta menyatakan tingkat kelayakan padarangka alat pengujian pompa.

\subsection{Tujuan Penelitian}

Penelitian ini bertujuan untuk merancang sebuah konstruksi rangka yangkokoh dan kuat untuk menopang beban semua komponen peralatan pengujianpompa.Rancangan konstruksi rangka ini meliputi :

a. Perhitungan gaya dan tegangan yang diterima rangka.

b. Pemilihan bahan dan penentuan dimensi rangka.

c. Analisis desain konstruksi rangka alat pengujian pompa menggunakan program Catia V5.

\section{TEORI DASAR}

\subsection{Pengertian Umum}

Alat pegujian pompa-pompa adalah sebuah instrumen dengan instalasiterpadu yang tersusun atas beberapa sistem didalamnya. Sistem-sistem pada alatpenguji pompa antara lain sistem kelistrikan, sistem perpipaan fluida, sistempenggerak, sistem pemindah daya (power train), pompa-pompa dan konstrusirangka.

Alat penguji pompa-pompa berfungsi sebagai pembanding karakteristikbeberapa jenis pompa yang berbeda. Pengujian pompa dilakukan dengan caramengkodisikan putaran pompa serta mengatur tekanan fluida pada sistemperpipaanya, sehingga didapat data-data penelitian yang bervariasi yang

Selanjutnyadigunakan sebagai acuan untuk menentukan karakter tiap-tiap pompa.

\subsection{Jenis Pembebanan}

Beban dalam balok dapat dibedakan sebagai beban terpusat dan bebanmerata. Sebuah beban terpusat adalah beban yang bekerja pada jarak yang sangatkecil sehingga dapat dianggap bekerja pada suatutitik, sebaiknya beban merata bekerjadisepanjang balok tertentu. Beban bisa terbagi rata diatas seluruh panjang ataudiatas bagian panjang, seperti tampak pada Gambar 1 di bawah.

Pada beban merata yang bervariasi atau beban segitiga, intensitaspembebanan bertambah atau berkurang dengan laju tetap. Kondisi ini bisa timbul,misalnya akibat tekanan air yang bekerja pada permukaan, bendungan atautumpukan pasir.

Diagram untuk jenis pembebanan intensitas beban merata maksimumadalah W pada bagian tengah dan menurun ke nol pada tumpuan.

Pada penerapan desain struktur beban dibedakan menjadi dua yaitu bebanmati dan beban hidup. Beban mati adalah beban statis yang dihasilkan gayaverikal karena gravitasi, termasuk berat kerangka struktur dan semua materialyang secara permanen ditempatkan pada struktur serta tumpuan yang menopangstruktur.

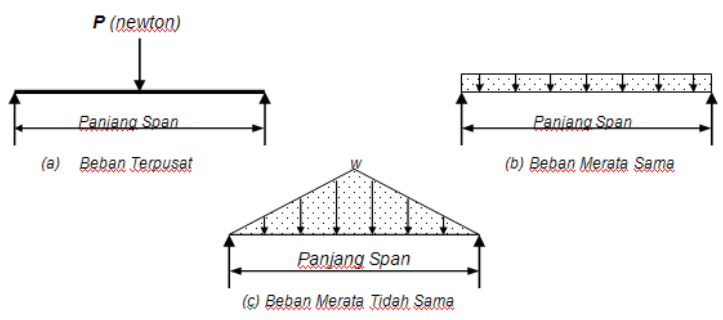

Gambar 1. Jenis-Jenis Pembebanan

Beban hidup dapat didefinisikan sebagai semua beban yang bukan bebanmati. Beban pada umumnya terjadi sebagai kombinasi beban mati dan bebanhidup sehingga keduanya harus diperhitungkan dalam desain rangka struktur.

\subsection{Kriteria Pemilihan Material}

Faktor-faktor yang mempengaruhi pemilihan material dalam merancangbangun kontruksi rangaka penunjang adalah : 
a. Sifat mekanis seperti: kekakuan, keuletan, kekerasan, elastisitas,ketangguhan, kekuatan terhadap berat dan kekakuan terhadap berat.

b. Safat fisis seperti: densitas, titik lebur, muai termal, konduktivitastermal, sifat elektrik, sifat optik dan sifat magnetik.

c. Sifat kimia seperti: oksidasi, korosi, degradasi dan flammability.

d. Sifat yang dibutuhkan selama operasipembentukan seperti : mampumesin, mampu las, mampu tempa, karakteristik pengerjaan panas,karakteristik pengerjaan dingin.

e. Ketersediaan dan harga bahan baku.

f. Pengaruh proses terhadap sifat akhir material.

g. Pengaruh waktu dan pemakaian.

h. Daur ulang dan pembuangan material

\subsection{Unit Rangka}

Rangka berfungsi sebagai pendukung dan berperan sebagai dudukankomponen-komponen alat penguji pompa-pompa. Rangka memiliki tugas sebagaipenopang keseluruhan beban dari komponen yang dipasangkan pada rangka,misalnya: panel listrik, motor listrik, gear pump, piston pump, centrifugal pump,hydromotor, tangki fluida dan peralatan penting lainya.

Kriteria perancangan yang paling penting adalah faktor keamanan, karenahal ini berpengaruh pada kelayakan sebuah desain konstruksi. Pendekatan palingumum dari analisis keamanan suatu struktur didasarkan pada asumsi bahwa jikategangan yang diterima rangka lebih kecil dibandingkan tegangan-teganganmaksimal yang berpotensi menyebabkan kegagalan suatu struktur, makakeamanan pada struktur terjamin.

Beban kerja aksial biasanya lebih kecil dibandingkan beban kerja teoritis,sehingga dapat digunakan sebagai patokan untuk mewakili beban minimum yangterjadi selama umur sebuah struktur konstruksi tersebut. Tegangan yang diterimasuatu konstruksi tidak boleh melewati tegangan yang diizinkan dari materialpenyusunya.

\subsection{Progaram Catia}

CATIAadalahsalah satu program komputer yang dikembangkan oleh perusahaanperangkat lunak (software) terkenal bernama IBM. Program ini banyak digunakanuntuk keperluan teknik karena fitur-fiturnya yang sangat baik untuk melakukanCAD (Computer Aided Desain), CAM (Computer Aided Manufacture) serta CAE(Computer Aided Engineering). Keunggulan Catia V5 yang lain yaitu mampumelakukan analisis keuatan sebuah desain serta menyajikanya dalam bentuk 3Dyang menarik.

Pada program Catia V5 terdapat beberapa pilihan menu operasional,diantaranya adalah :

a. Infrastructure yaitu basic program yang dimiliki oleh Program Catia V5.

b. Mechanical Desain yaitu menu yang buat untukmempermudahpengguna untuk membuat suatu desain mekanik.

c. Analysis and Simulation yaitu fitur Catia V5 yang mampu melakukananalisis kekuatan suatu desain serta menampilkanya dengan simulasi yangsangat menarik.

Pada penelitian ini pengunaan program catia V5lebih diarahkan padapenggunaan menu mechanical design dan analysis and simulation untukmenunjang perancangan konstruksi rangka alat pengujian pompa-pompa.

Pembuatan model rangka menggunakan program Catia akan sangat membantu timdalam mendapatkan visualisasi rangka secara 3D, sedangkan analisis kekuatanrangka sangat berguna dalam penentuan jenis material serta upaya perbaikandesain.

Pembebanan yang dialami konstruksi rangka oleh komponen-komponenalat pengujian pompapompa akan mengakibatkan tegangan dan regangan yangberpotensi merusak konstruksi rangka. Untuk mencegah terjadinya kerusakanyang diakibatkan hal tersebut, maka dilakukan studi analisis tegangan statis untukmengetahui tegangan maksimal yang diterima rangka, serta menentukan daerahkritis pembebanan. Dengan menggunakan program Catia V5 dalam proses desaindan analisis kekuatan, diharapkan akan diperoleh desain terbaik rangka alatpengujian pompa.

\section{METODOLOGI PENELITIAN}

Dalam mendesain atau merancang sebuah rangka diperlukan urutan kerjayang sistematis 
dan terencana guna mendapatkan hasil kerja yang optimal.

Dengan perencanaan dan penelitian yang matang serta komitmen yang tinggi terhadap pelaksanaan pekerjaan maka akan dicapai efektifitas dan efisiensi pekerjaan yang tinggi. Tahapan penelitian yang dilakukan dalam perancangan konstruksi rangka dijelaskan pada Gambar 2 di bawah.

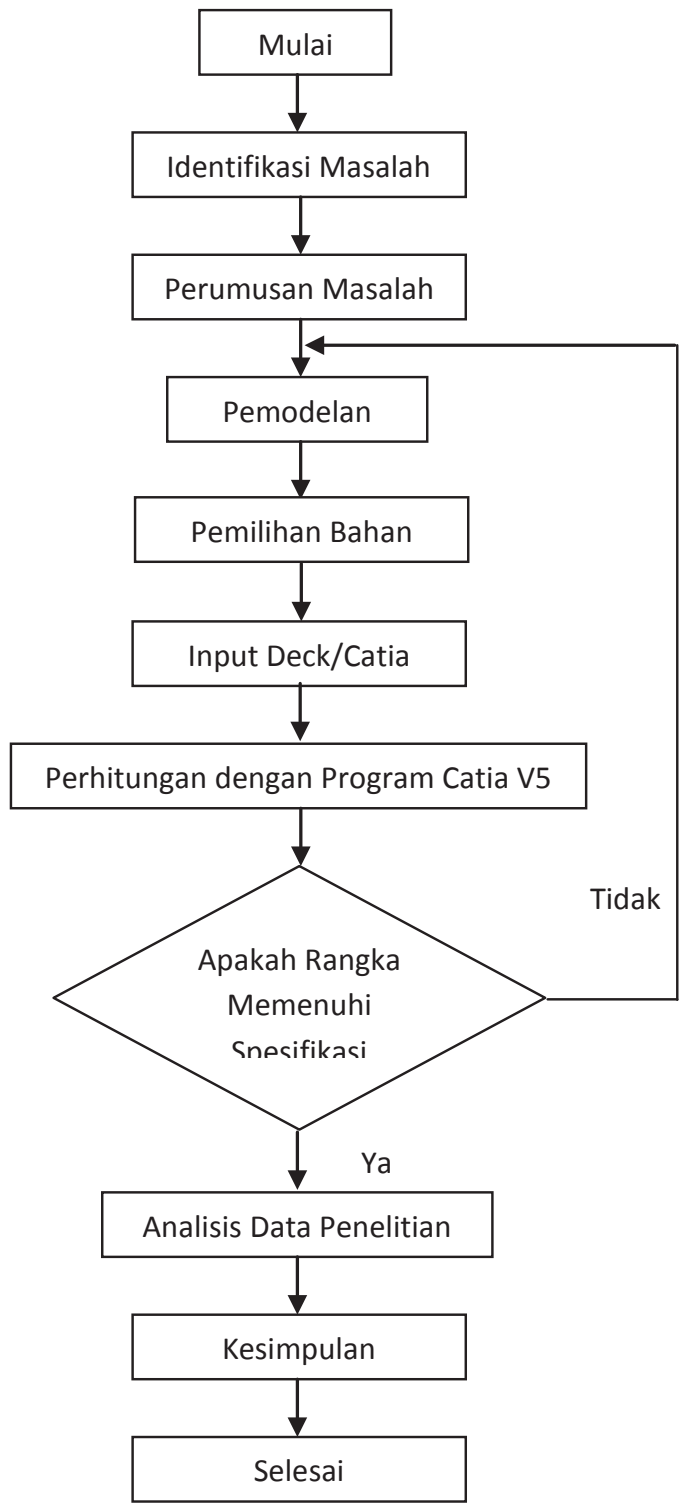

Gambar 2. Alur Penelitian

\section{HASIL DAN PEMBAHASAN}

\subsection{Tegangan pada Rangka}

Penempatan komponen alat pengujian pompa pada rangka dengan massatotal sebesar 84,5 kg mengakibatkan terjadinya gaya pembebanan sebesar 828.945N pada sumbu Z rangka, dengan arah vertikal kebawah menuju pusat bumi(negatif). Distribusi tegangan yang terjadi pada rangka digambarkan denganwarna yang bervariasi, warna biru melambangkan nilai tegangan yang terjadi padarangka sengat kecil dan tidak akan membahayakan konstruksi rangka. Warnakuning hingga merah melambangkan nilai tegangan yang cukup tinggi sehinggaperlu untuk diwaspadaiseperti terlihat pada Gambar 3.
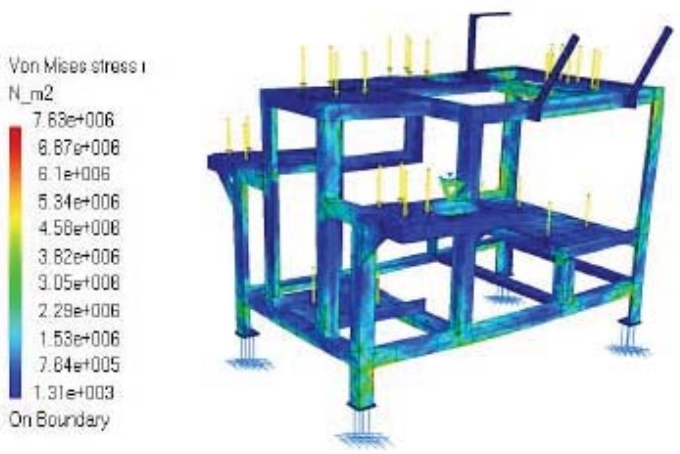

Gambar 3. Distribusi Tegangan pada Rangka

Berdasar pada perhitungan yang dilakukan dengan program CATIA V5tegangan tertinggi (maximum stress) rangka terletak pada kaki rangka, yaknidengan nilai 7.63027 x 106 N/m² seperti terlihat pada Gambar 4. Nilai tegangantertinggi rangka masih lebih rendah dibanding dengan nilai tegangan luluhmaterial (Yield strength) yaitu sebasar 2.5 x 108 N/m².

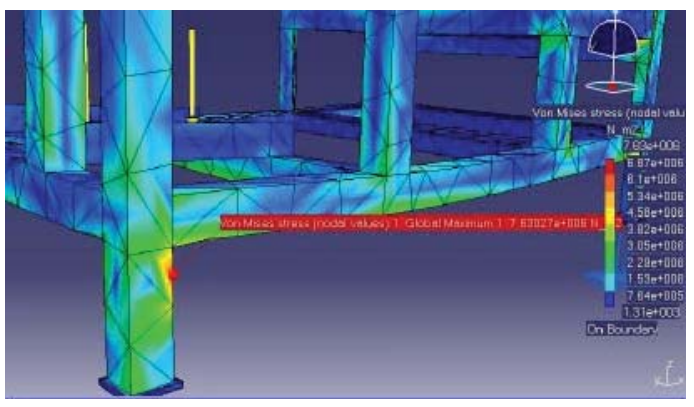

Gambar 4. Distribusi Tegangan pada Rangka 


\subsection{Regangan pada Rangka}

Gaya pembebanan pada alat pengujian pompa menyebabkan terjadinyadefleksi pada rangka seperti terlihat pada Gambar 5. Area yang berwarna birupada rangka menandakan bawasanya pergeseran yang terjadi dengan nilai yangrelatif kecil yaitu 0 - 0.00408 mm. Area dengan warna merah menandakan bahwaarea tersebut telah mengalami pergeseran dengan nilai yang cukup tinggi sehinggaperlu perhatian khusus.

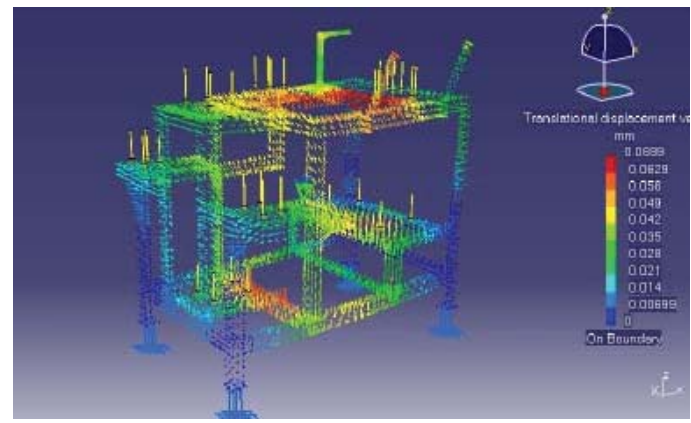

Gambar 5. Distribusi Regangan pada Rangka

Dari hasil analisis menggunakan program CATIA V5 didapatkan nilaidefleksi terbesar yang terjadi pada rangka yaitu sebesar $0.0699382 \mathrm{~mm}$. Lokasipergeseran maksimum terletak pada bagian atas rangka, yaitu area yang diidentifikasi dengan warna merah seperti terlihat pada Gambar 6 . Nilaipergeseran ini sangat kecil dan tidak akan teridentifikasi secara visual. Nilaidefleksi yang terjadi menunjukan bahwa secara keseluruhan konstruksi rangkadalam keadaan baik, dan mampu menopang komponen-komponen diatasnyatanpa mengalami pergeseran yang berarti.

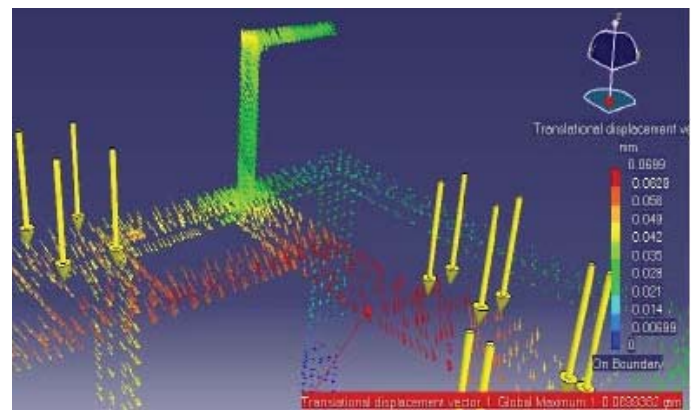

Gambar 6. Regangan Maksimum pada Rangka

Uraian diatas menegaskan bahwa desain konstruksi rangka alat penggujianpompa dengan dimensi panjang $1000 \mathrm{~mm}$, lebar $540 \mathrm{~mm}$, tinggi 820 mm danmenggunakan material baja karbon SC40 profil "L” dengan panjang $40 \mathrm{~mm}$, lebar40 $\mathrm{mm}$ dan tebal $4 \mathrm{~mm}$, merupakan konstruksi rangka yang kokoh dan kuat.

\section{KESIMPULAN}

Berdasarkan hasil analisis terhadap konstruksi rangka alat pengujianpompa menggunakan program CATIA V5, dapat diambil kesimpulan sebagaiberikut:

a. Distribusi tegangan dan regangan pada rangka alat pengujian pompaditunjukan dengan variasi warna pada hasil analisis dengan programCatia V5. Tegangan maksimum yang diderita rangka adalah sebesar7.63027 x $106 \mathrm{~N} / \mathrm{m}^{2}$ terletak pada kaki rangka dibawah piston pump.

b. Spesifikasi rangka alat pengujian pompa adalah baja siku SC 40 denganpanjang 1000 $\mathrm{mm}$, lebar $540 \mathrm{~mm}$ dan tinggi $820 \mathrm{~mm}$.

c. Material konstruksi alat pengujian pompa adalah baja SC 40 denganbatas tegangan bahan yang diijinkan yaitu sebesar $2.5 \mathrm{X}$ $108 \mathrm{~N} / \mathrm{m}^{2}$

d. Defleksi maksimum yang terjadi pada rangka alat pengujian pompasebesar $0.0699382 \mathrm{~mm}$, terletak pada bagian atas rangka yaitu padadudukan hydromotor.

Hasil analisis kekuatan menggunakan program Catia V5 terhadap strukturrangka alat pengujian pompa menunjukan bahwa rangka memiliki kekuatan yangmemadai untuk menopang komponen diatasnya.

\section{REFERENSI}

1. Anonim, Teknik Mesin, IBM Catia Basic Training Module, PoliteknikNegeri Bandung, Bandung, 2007.

2. Anonim, Teknik Mesin, Modul Pelatihan Catia, Universitas Nasional,Jakarta, 2009.

3. Hendriansyah, H. dan Rahman, A, Elemen Mesin Konstruksi dari BangunanMesin, Erlangga, Jakarta, 1981.

4. J.E, Shigley, (Terjemah: G Harahap), Perencanaan Teknik Mesin, Erlangga,Jakarta, 1984. 
5. Sujiarto, Irvan, Desain dan Analisis Struktur Konstruksi PerangkatDesalinasi Mechanical Vapour Compression Dengan Catia V5,UniversitasNasional, Jakarta, 2008. 